\title{
Nutritional status of upper primary school pupils in a rural setting in Ghana
}

\author{
Angelina Opoku Danquah ${ }^{1,}$, Adwoa Nyantakyiwaa Amoah ${ }^{2}$, Clara Opare-Obisaw $^{1}$ \\ ${ }^{1}$ Department of Family and Consumer Sciences, University of Ghana, Legon, Ghana \\ ${ }^{2}$ Department of Home Economics Education, University of Education, Winneba, Ghana
}

\section{Email address:}

adanquah@ug.edu.gh(A. O. Danquah)

\section{To cite this article:}

Angelina Opoku Danquah, Adwoa Nyantakyiwaa Amoah, Clara Opare-Obisaw. Nutritional Status of Upper Primary School Pupils in a Rural Setting in Ghana. International Journal of Nutrition and Food Sciences. Vol. 2, No. 6, 2013, pp. 320-326. doi: $10.11648 /$ j.ijnfs.20130206.19

\begin{abstract}
Malnutrition continues to be a major problem among school-aged children in developing countries. In Ghana, there is not much documented data on the nutritional status of this category of children. Thus, this cross-sectional study was conducted to assess the nutritional status of 120 upper primary school pupils, comprising 60 males and 60 females in a rural setting. These pupils were randomly selected from 3 public schools in 3 villages with similar socioeconomic characteristics in the Atwima-Nwabiagya District of the Ashanti region of Ghana. A pretested structured questionnaire was used to collect information on socio-demographic characteristics and food consumption patterns of the pupils while an electronic bathroom scale and microtoise stadiometer were used to obtain their weights and heights, respectively. A 24-hour dietary recall was used to assess the nutrients and energy intakes and the ESHA food processor nutrients database was employed in the analysis of energy and nutrients. To assess stunting and underweight among the respondents, WHO/Epi software was used. T-test and chi-squared statistic were used to analyze differences between variables. The results of the study revealed that almost half of the pupils reported eating three times daily with breakfast and lunch mainly consumed from the school canteen. The 24-hour recall showed that the pupils did not meet their energy and nutrient requirements except for five out of the twelve nutrients investigated. The prevalence of stunting and underweight were $56.7 \%$ and $45.8 \%$, respectively, among the respondents. More males than females were either stunted or underweight. However, no significant difference was found between males and females in the incidence of stunting and underweight. The prevalence of thinness also showed that $5 \%$ of the males were thin and $13.5 \%$ females were overweight/obese. It was concluded that the nutritional status of the respondents was poor since the incidence of stunting and underweight were high while energy and some nutrients were below the recommended intakes. The researchers recommended that there should be more effort in designing intervention programs to improve the quality of meals the pupils consume and also there should be more emphasis on nutrition education at the primary level in rural areas.
\end{abstract}

Keywords: Nutritional Status, Anthropometric Indicators, Nutrient Intakes, School-Aged Children, Rural Setting

\section{Introduction}

The school-aged child is likely to spend a greater part of the day at school. Therefore, increasing numbers of meals are eaten away from home, often at establishments where adherence to food safety measures is difficult and may affect good nutrition [1]. The nutritional needs of the school-aged child are high because they participate in school group activities such as sports and recreational programs. The influence of peers and significant adults, like teachers or sports idols, is also increased while friendships and other social contacts become more important [2]. While the upper primary school pupils are usually between the ages of 9-12 some may be older due to late start of school. Thus, most of these pupils may be classified as early adolescents. The adolescent is considered especially vulnerable nutritionally because there is an increased demand for nutrients related to the dramatic increase in physical growth, psychosocial and cognitive development. Moreover, the changes in their lifestyle and food habits affect both nutrient intakes and needs. There are also special nutrient needs with participation in sports, use 
of drugs, development of an eating disorder and excessive dieting which are associated with adolescence [2]. Williams and Schlenker [3] asserted that both food and nutrition security promote optimum nutritional status and that both sexes of adolescents can be at risk of dietary excesses and deficiencies.

The vast majority of school children in developing countries, like Ghana, attend day primary schools, a few of which provide a mid-day meal. In rural areas where schools may be some kilometers away from home, the children frequently have to leave home early and walk a considerable distance to school. Often the children have little or no breakfast at home before setting off to school and this leads to nutrient deficiencies as reported by Intiful and Lartey [4]. In the United States of America and other developed countries however, there are school feeding programs like the National School Lunch and School Breakfast Programs which children participate in [5]. Because of the high nutritional needs of school children, the FAO recommends that, it is highly desirable that children eat some food before going to school. They should also consume some meals at school at mid-day in addition to the food eaten at home. Such a mid-day meal should provide reasonable amounts of the nutrients most likely to be missing or short in the home diet [5]. However, a midday meal which may be provided by the government or local authority as part of school meals is unavailable in the educational system of most developing countries. In the absence of school lunch, Latham [5] reported that entrepreneurs set up stalls near the schools so they can prepare and sell foods to school children. Even though such stalls often have the advantage of providing access to cooked foods to school children, there are disadvantages including poor hygiene, poor quality food and high prices. Where the main source of food for school children is a vendor, the food is available only to children who have money to purchase it. Hence the wealthier children can purchase food and children from poor families or those whose parents will not provide money may not [5].

Although the health, cognition and educational achievement of school-aged children are influenced by their nutritional status, school-aged children are not usually part of health and nutrition surveys as reported by Best and co-workers [6]. Best et al. [6] found out from their study that malnutrition is a major concern in school-aged children. Several studies have also confirmed the prevalence of malnutrition and micronutrient deficiencies in school children in developing countries [7-10].

In Ghana, there is paucity of documented information on the nutritional status of school-aged children and such studies could help in the development of relevant nutrition intervention by stakeholders to address issues of malnutrition among school children. It was against this background that the study was conducted to assess the nutritional status of primary school pupils in a rural setting in Ghana and to document incidence of malnutrition among school-aged children.

\section{Methodology}

\subsection{Study Design and Sampling}

A cross-sectional survey was carried out in three public schools randomly selected from three villages in the Atwima-Nwabiagya District of the Ashanti Region of Ghana. These villages were selected based on similar socioeconomic characteristics in order to have a fair representation of primary school pupils in the rural community. One hundred and twenty primary five pupils, comprising 60 males and 60 females, participated in the study and this class was chosen for convenience. The pupils were randomly selected using the class register where every $3^{\text {rd }}$ pupil was chosen.

\subsection{Data Collection and Analysis}

Permission was sought from the District Education Office to conduct the study after which the head teachers of the schools requested the consent of the caregivers of the pupils. Pupils whose caregivers declined their participation were not included. In addition, verbal consent was sought from all the pupils before the study begun. A pretested structured questionnaire was used to collect information on socio-demographic characteristics and food consumption patterns of the pupils and the data were analyzed using the Statistical Package for Social Scientist (SPSS, version 16). Anthropometric measurements taken were weight, to the nearest $0.1 \mathrm{~kg}$ and height, to the nearest $0.1 \mathrm{~cm}$. A $150 \mathrm{~kg}$ capacity electronic bathroom scale was used for the weights and a Microtoise stadiometer for the heights. Measurements were taken in duplicates and the average used. The 24-hour dietary recall method was used to assess the energy and nutrient intakes of the pupils. The ESHA Food Processor Nutrient Database (FPRO, Version 6.2) was used for the analyses of energy and nutrients. The Recommended Nutrient Intakes by WHO/FAO $(2003,2004)$ served as the reference. For the standard deviation scores for HAZ and WAZ from the weight and height measurements, the WHO/Epi info (Version 3.4.1) was used to determine stunted and/or underweight pupils. The WHO growth reference data for 5-19 years was employed to compute standard deviation scores for BMI-for age used in assessing thinness among pupils. T-tests were used to analyze differences between variables.

\section{Results and Discussion}

\subsection{Background of Pupils}

\subsubsection{Age of Pupils}

The pupils in the study ranged in ages from 9 to 17 years with a mean age of 13 years. About $40 \%$ of the pupils were too old to be in primary school and this is because in rural settings some children start school when they are much older as reported by the Institute of Food Research Programmes and may also be due to poor health (IFPRI) [11]. It has also been reported that malnourished children in 
Ghana start school at a late age with some dropping out after fewer years of school [12].

\subsubsection{Caregivers of Pupils}

The caregivers of pupils are presented in Table 1. The caregivers were the individuals with whom the pupils were staying and seeing to their day-to-day upkeep at the time of the study. A little over half of the pupils (51.3\%) were under the care of both parents. There were more pupils living with only their mothers $(21.8 \%)$ than with their fathers $(6 \%)$. The remaining $11 \%$ were under the care of their guardians (uncles, aunts, siblings and family friends). Bronte-Tinkew and Dejong [13] in a study conducted in Jamaica to assess the influence of household structure and resource dilution characteristics on children's nutritional status concluded that living in a single parent and cohabiting household increases the odds of stunting in children. They also found out that children who have low height-for-age were from single-parent, low income families with siblings. In South Africa, a study conducted on the nutritional status and household patterns of children revealed that children from male headed households suffered chronic malnutrition [14]. Cataldo et al. [15] also said that single parent households which are predominantly headed by women with mean lower income and less money for all expenses, including food, compared to those households headed by men.

Table 1. Caregivers of Pupils

\begin{tabular}{ccc}
\hline Caregiver & N & \% \\
\hline Both parents & 54 & 45.0 \\
Mother & 30 & 25.0 \\
Guardian & 27 & 22.5 \\
Father & 9 & 7.5 \\
Total & 120 & 100.0 \\
\hline
\end{tabular}

\subsubsection{Occupation and income of Caregivers}

Table 2 shows that generally, the predominant occupations of the caregivers were petty trading and subsistence farming. The 2003 Ghana Health and Demographic Report as presented by Ghana Statistical Services, Noguchi Memorial Institute for Medical Research and Macro International Inc. [16] on the labor force of the district established trading and farming as the major occupations in the area. From the occupation profiles of the caregivers of the pupils given, it was evident that these pupils were coming from families which were not financially very well to do. Comparing the incomes of the caregivers revealed that there was not much difference in the amounts those employed were making at the end of the month and that the caregivers were in the low income bracket (figures not shown). Low socio-economic status and high fertility have been indicated to be among the factors that influence the nutritional status of an individual [16]. It has been reported that children from low and middle income countries are always at increased risk of under nutrition due to poverty and lack of food [17]. Such children have also been found to be at risk of overweight or obesity since they consume low-cost, high calorie and energy-dense foods.

Table 2. Occupation of Caregivers

\begin{tabular}{llll}
\hline Occupation & Mothers & Fathers & Guardians \\
\hline Petty Trading & 77.8 & 23.8 & 51.9 \\
Farming & 7.7 & 50.8 & 29.6 \\
Artisans & 5.6 & 7.9 & 7.4 \\
Salaried Workers & 6.7 & 12.7 & 0.0 \\
Unemployed & 2.2 & 4.8 & 11.1 \\
\hline
\end{tabular}

$\mathrm{N}=120$

\subsubsection{Household Size}

The household size of the pupils ranged from 5 to 7 with a mean of $5.83 \pm 2.248$. This showed that pupils came from homes with more dependants to cater for which meant there were many persons in the household to share a plate of food [13]. Large family size implies that distribution of resources will be meager for each individual and this is translated into the nutritional health of family members with children being affected the most.

\subsection{Mean Energy and Nutrient Intakes}

Almost half of the pupils (49.6\%) reported eating three times while $37.8 \%$ ate four times daily. The rest $(12.6 \%)$ ate more than five times a day. The sources of breakfast and lunch were the school canteen and home while supper was mainly consumed at home. Since the school canteen was the main source of both breakfast and lunch among most of the pupils, there is the need to ensure that the kind of food sold to children in these schools are wholesome and nutritious given that, these children are restricted to choose from what is available in school. Research has it that foods sold in school canteens have a significant role in ensuring children consume healthy and nutritious meals as school canteens provide a positive influence on pupils who are developing their eating habits [18].

On the whole, the 24-hour recall revealed that the pupils did not meet their energy and nutrients requirement except for five out of the twelve nutrients investigated (Table 3 ). This is of much concern due to the fact that the pupils were at a stage of rapid growth and development and, thus, inadequate intake of certain nutrients might adversely affect them. Adequate energy intake is essential for vital body processes like basal metabolism and physical activity and this would even spare proteins for more important functions like hormone and enzyme production and building of tissues instead of energy generation [19]. The findings, therefore, indicate that the number of times pupils ate did not positively influence their energy intakes which might probably be due to the quantities and quality of meals consumed. Inadequate quality and quantity of food are causes of nutrition problems in adolescents. The 
carbohydrate intakes exceeded the recommended (193.1\%RNI) and this was because most diets consumed were from starchy staples such as cassava, corn and rice. The recommended protein intakes were not met $(72 \% \mathrm{RNI})$ with the protein coming mostly from legumes and nuts. There is the need for these pupils to increase the intake of protein given the important role protein plays in growth and development. Iron intakes were very adequate $(16.5 \mathrm{mg} / \mathrm{d})$ and as reported by Davies [20] plant sources provide about two-thirds of iron in human diets which was the case among the pupils studied. This is a positive finding since iron deficiency is the commonest in the world and can lead to reduced physical growth and mental health problems [21]. The mean zinc intakes of $8.9 \mathrm{mg}$ were adequate for the day since it represented more than two-thirds of the RNI [22]. Zinc deficiency results in stunted growth and poor sexual development later in life. The intakes of vitamins A, $\mathrm{B}_{12}$ and $\mathrm{C}$ exceeded the requirements. The high intakes of vitamin A could be attributed to the frequent consumption of palm-fruit soup, palm oil in sauces and the high intake of mangoes which were in season at the time of the study.
Palm oil is known to provide most of the vitamin A activity in the diets of economically deprived populations [21] and is necessary for good eyesight. Palm oil has carotenoids and tocopherols in abundance. Oranges abound in the Atwima-Nwabiagya district, the study site, and could explain the high intakes of vitamin C. Intakes of dietary phosphorus, calcium, thiamin, folate and riboflavin were generally low. Optimal calcium intakes is crucial for adolescents to attain their full genetic potential for peak bone mass which will help prevent osteoporosis later in life [23]. Several studies in Ghana and elsewhere have confirmed low intakes of calcium among children $[4,24$, 25]. The finding that the pupils did not meet the RNI for thiamin and riboflavin is a matter of concern given the fact that these vitamins are involved in energy metabolism. Deficiency of such vitamins results in anorexia, decreased growth, muscle weakness and lack of coordination [26]. The protective role played by vitamins in disease prevention makes it imperative that pupils receive adequate amounts.

Table 3. Means of Energy (calories) and nutrient intakes of pupils from a 24-hour recall

\begin{tabular}{|c|c|c|c|}
\hline Nutritional components & Mean & \pm SD & $\%$ RNI \\
\hline$(\mathrm{RNIs})^{*}$ & & & Met \\
\hline Calories kcal (1950-2400) & 1135.0 & 504.4 & 52.2 \\
\hline Carbohydrate g (130) & 251.8 & 17.4 & 193.1 \\
\hline Protein $\mathrm{g}(34.5-44.2)$ & 26.3 & 44.6 & 66.8 \\
\hline Iron mg (14-15) & 15.3 & 28.9 & 103.4 \\
\hline Phosphorus mg (1250) & 673.5 & 262.8 & 53.9 \\
\hline Calcium mg (1300) & 343.6 & 214.2 & 26.4 \\
\hline Zinc mg (7.8-9.2) & 6.7 & 3.0 & 78.8 \\
\hline Vitamin A ug RE (600) & 1214.2 & 113.2 & 206.8 \\
\hline Vitamin C mg (40) & 95.8 & 132.9 & 239.5 \\
\hline Vitamin $\mathrm{B}_{1} \mathrm{mg}(1.1-1.2)$ & 0.6 & 0.3 & 51.2 \\
\hline Vitamin $B_{2} \operatorname{mg}(1.0-1.3)$ & 0.5 & 0.2 & 35.9 \\
\hline Vitamin $\mathrm{B}_{12} \mathrm{mg}(2.4)$ & 2.5 & 24.3 & 104.2 \\
\hline Folate mg (400) & 18.5 & 28.9 & 4.6 \\
\hline
\end{tabular}

*Source: RNIs for calories and nutrients adopted from WHO \& FAO (2004)

\subsection{Nutritional Status of Pupils}

The weights, heights and BMIs of pupils are presented in Table 4. The BMI shows that generally the pupils were underweight. It was expected that most pupils would be within the normal BMI range due to the fact that they might have variety of food choices both at home and in school. However, the study revealed otherwise. In Ghana, there are certain taboos especially in some rural areas which forbid the intakes of certain food items. Such practices influence ones food choice and thus impacts nutritional status in the long run. A study by Rea [27] as reported by Amos et al. [28] reiterated that religious, political or social beliefs are factors informing the food choices certain individuals make.
Table 4. Weights, heights and BMIs of pupils

\begin{tabular}{lll}
\hline Measurements & Mean & 土SD \\
\hline Weights $(\mathrm{kg})$ & 36.7 & 8.2 \\
Height $(\mathrm{cm})$ & 144.6 & 8.6 \\
BMI $\left(\mathrm{kg} / \mathrm{m}^{2}\right)$ & 17.4 & 2.6 \\
\hline
\end{tabular}

$\mathrm{N}=120$

Comparing these indicators by gender showed that the female pupils were heavier and slightly taller than their male counterparts (Table 5). This difference could be attributed to the fact that on the average, girls begin the process of puberty earlier than boys which most likely 
increases their weight. The t-test indicated statistically significant differences in the weights $(p=0.000)$, heights $(p$ $=0.002)$ and BMI $(p=0.003)$ between the two sex groups.

Table 5. Comparison of Weights, heights and BMIs by sex

\begin{tabular}{llllll}
\hline Measurements & Males & \multicolumn{5}{c}{ Females } \\
& Mean & 土 SD & Mean & 土 SD & p-value \\
\hline Weights $(\mathrm{kg})$ & 34.0 & 7.1 & 39.5 & 8.3 & 0.000 \\
Heights $(\mathrm{cm})$ & 142.1 & 9.5 & 144.6 & 7.5 & 0.002 \\
BMI $\left(\mathrm{kg} / \mathrm{m}^{2}\right)$ & 16.7 & 2.3 & 18.1 & 2.7 & 0.003 \\
\hline
\end{tabular}

Significance was at $\mathrm{p}<0.05$

Table 6 shows the means and standard deviations of the anthropometric indicators used in assessing nutritional status (WAZ, HAZ and BMI-for-age). The findings indicated significant differences in HAZ (heights-for-age) $(p=0.002)$ and BMI-for-age $(p=0.031)$ while there was no significant difference in WAZ (weights-for age) ( $p$ $=0.123$ ) between the male and female pupils.

Table 6. WAZ, HAZ and BMI-for-Age of pupils

\begin{tabular}{lcclll}
\hline Indices & Males & \multicolumn{5}{c}{ Females } \\
& Mean & \pm SD & Mean & 土 SD & p-value \\
\hline WAZ & -1.1 & 0.9 & -0.6 & 0.8 & 0.123 \\
HAZ & -1.2 & 1.0 & -0.9 & 1.0 & 0.002 \\
BMI-for-Age & -0.6 & 1.3 & -0.2 & 1.1 & 0.031 \\
\hline
\end{tabular}

Significance was at $\mathrm{p}<0.05$

Generally, $45.8 \%$ of the pupils were underweight (Table 7). More males (60\%) than females (31.7\%) showed various degrees of underweight but the difference was not statistically significant $(p=0.147$ ). No pupil was found to be severely underweight. A study conducted by Puckree et al. [29] on primary school children in eThekwini district in KwaZulu-Natal, South Africa found out that a significant number of the pupils were underweight.

Table 7. Prevalence of underweight among pupils

\begin{tabular}{lll}
\hline Degree of & \% Males & \% Females \\
\hline Underweight & $\mathrm{N}=60$ & $\mathrm{~N}=60$ \\
Normal weight & 40.0 & 68.3 \\
Mildly underweight & 41.7 & 28.4 \\
Moderately underweight & 18.3 & 3.3 \\
Severely underweight & 0.0 & 0.0 \\
\hline
\end{tabular}

$\chi 2=3.830, \mathrm{df}=2, \quad \mathrm{p}=0.147$

Table 8 indicates that more males $(63.3 \%)$ than females $(50 \%)$ exhibited various degrees of stunting even though the difference was not statistically significant $(\mathrm{p}=0.147)$ between males and females. On the whole $56.7 \%$ of the pupils were stunted. In terms of underweight and stunting, it appears females were better than their male counterparts. Some studies have shown that the nutritional status of girls is better than that of boys in their study groups in Mozambique [30] and Boirahmad rural areas in Iran [31]. Stunting represents the long term effect of malnutrition in an individual or population and does not vary according to recent dietary intakes. According to the Administrative Committee on Co-ordination/ Standing Committee on Nutrition [32], stunting affected an estimated 32.5\% of children in developing countries. It could be inferred that chronic malnutrition was prevalent in the school age children of this study which is indicative of extended periods of inadequate food intakes of pupils. Most of the school-age children in the slums of India have been reported to have poor nutritional status [7].

Table 8. Prevalence of stunting among pupils

\begin{tabular}{lll}
\hline Degree of & $\%$ Males & $\%$ Females \\
\hline Stunting & $\mathrm{N}=60$ & $\mathrm{~N}=60$ \\
Normal height & 36.7 & 50.0 \\
Mildly stunted & 41.7 & 40.0 \\
Moderately stunted & 21.6 & 10.0 \\
Severely stunted & 0.0 & 0.0 \\
\hline
\end{tabular}

$\chi^{2}=3.830, \mathrm{df}=2, \mathrm{p}=0.147$

The findings again revealed that more females (13.6\%) were overweight or obese than their male counterparts $(5.0 \%)$ as shown in Table 9. No female pupil was thin while $5 \%$ males were thin with none being severely thin in this study. On the whole, $15 \%$ pupils were overweight/obese and this should be of concern. The chi square test showed no significant difference between males and females regarding prevalence of thinness/overweight. Adamu et al. [33] found out in their study on the effects of dietary patterns on the nutritional status of upper primary school children in Tamale metropolis in Ghana that $4 \%$ of the pupils were overweight while $10 \%$ were underweight. However, a survey on prevalence of obesity among school children in the Achimota Legon, area, Ghana, showed that $26.4 \%$ of the respondents were underweight and $19.3 \%$ being obese [34].

Table 9. Prevalence of thinness and overweight among pupils

\begin{tabular}{lll}
\hline Degree of & \% Males & \% Females \\
\hline Thinness/overweight & $\mathrm{N}=60$ & $\mathrm{~N}=60$ \\
Normal & 90.0 & 86.7 \\
Overweight & 1.7 & 8.3 \\
Obese & 3.3 & 5.0 \\
Thin & 5.0 & 0.0 \\
Severely thin & 0.0 & 0.0 \\
\hline
\end{tabular}

$\chi^{2}=6.515, \mathrm{df}=3, \mathrm{p}=0.175$

Stunting, underweight, overweight and obesity have been shown to be among the nutritional challenges facing school children [9, 10] as reported by Intiful et al. [35]. The prevalence of underweight among school children is of 
much concern as reported [29]. Reports have it that in developing countries many boys and girls enter adolescence malnourished. This makes them prone to diseases and early death [36].

\section{Conclusions}

The study was set out to investigate the nutritional status of primary five pupils in some selected villages in the Atwima-Nwabiagya district of the Ashanti region of Ghana. A 24-hour recall was used to assess the nutrients and energy intakes of the pupils and the findings showed that they did not meet their energy and nutrient requirements. Anthropometric indicators studied revealed that there were high incidents of stunting and underweight even though most pupils ate more than three times daily. More boys were stunted or underweight than girls and more girls were overweight/obese than boys. Thus, it can be concluded that the nutritional status of the primary school pupils studied was poor. Based on these findings, it is recommended that there should be more effort in designing intervention programs including fortification of food items and diversification to improve the quality of meals consumed by these pupils that will in turn improve their nutritional status. Nutrition education must be emphasized at the primary school level in the rural areas.

\section{Acknowledgement}

The authors are most grateful to the primary five pupils in the Atwima-Nwabiagya district schools who participated in the study.

\section{References}

[1] Shills, M. E., Shike, M., Ross, C. A., Caballero, B. and Cousins, R. B, Modern Nutrition in Health and Diseases $\left(10^{\text {th }}\right.$ edition), Lippincott Williams and Wilkins, Philadelphia, 2006, 818-823.

[2] Mahan, L. K. and Escott-Stump, S, Food, Nutrition and Diet Therapy (10th edition), WB Saunders Company, United States, 2000, 257-262.

[3] Williams, S.R. and Schlenker, E, Essentials of nutrition and diet therapy, $8^{\text {th }}$ edition, The C.V. Mosby Co., St. Louis, 2003.

[4] Intiful, F.D. and Lartey, A, Breakfast habits of primary school children in the Manya Krobo District of the Eastern Region of Ghana. Thesis submitted to the Department of Nutrition and Food Science, University of Ghana, Legon, 2006.

[5] Latham, M. C, Human Nutrition in Developing World, FAO Food and Nutrition Series, No. 29. Rome, Italy. 1997, 53-57, 189-200.

[6] Best, C., Neufingerl N, van Geel, van den Briel, T and Osendarp, S, The nutritional status of school-age children: why should we care? Food and Nutrition Bulletin, 31(3),
400-417, September, 2010.

[7] Srivastava, A., Mahmood, S.E., Srivastava, P.M., Shrotriya, V.P. and Kumar, B, Nutritional status of school-age children - A scenario of urban slums in India. Arch Public Health, April 2010 17;70(1):8. doi: 10.1186/0778-7367-70-8. Available: http://www.ncbi.nlm.nih.gov/pubmed/22958757. Accessed August 6, 2013.

[8] Dabonè, C., Delisle, H.F. and Receveur, O, Poor nutritional status of schoolchildren in urban and peri-urban areas of Ouagadougou (Burkina Faso). Nutrition Journal, 19, 10-34, April 2011, Doi:1186/1475-2891-10-34. http:www.nsbi.nlm.nih.gov/pubmed/21504619. Accessed 8/6/2013.

[9] Jukes, M., McGuire, J., Method, F. and Sternberg, R, Nutrition: a foundation for development, Geneva: ACC/SCN, 2002, Available: http://www.bvsde.paho.org/texcom/nutricion/intnut2.pdf (August 4, 2013).

[10] Drake, L., Maier, C., Jukes, M., Patrikos, A., Bundy, D., Gardner, A. and Dolan, C, School-age children: their nutrition and health. Partnership for child development. 2002 , Available http://www.childdevelopment.org/Lists/PCD\%20Publication s/Attachments/55/PCD\%20ANNUAL\%20REPORT\%20LO W.pdf (15 July 2013).

[11] Department for International Development, A Second Chance for School Drop-out in Ghana, 2008. Available www. dfid.gov.uk. Accessed on 25/01/2009.

[12] Glewwe, P. and Jacoby, H, An economic analysis of delayed primary school enrollment and childhood nutrition in Ghana, 1994, LSMS Working Paper 98. World Bank, Washington DC.

[13] Bronte-Tinkew, J. and Dejong, G, Children Nutrition in Jamaica- Do Household Structure and Household Economic Resources Matter, Social Science and Medicine Journal, 55 (3), 499-514, 2003.

[14] Bertolis, S., Cardinal, S. and Veggiotti, P, Evaluation of Nutritional Status in Children. Nutrition Journal, 13(1), 513, 2006.

[15] Cataldo, C. B., DeBrunye, L. K. and Whitney, E. N, Nutrition and Diet Therapy (5 ${ }^{\text {th }}$ edition).West/Wadsworth Publishing Company, Belmont, 1999, 405-408.

[16] Ghana Statistical Services, Noguchi Memorial Institute for Medical Research \& Macro International Inc., Ghana Demographic and Health Survey. Calverton, Maryland, 2003, 183-190.

[17] WHO, Obesity and overweight, Fact sheet No. 311, Geneva, 2011 , Available: http://www.who.int/mediacentre/factsheets/fs311. Accessed September 30, 2013.

[18] Verity, C., Worsley, A. and Crawford, D, What are Grades 5 and 6 Children Buying from School Canteens and What Do Parents and Teachers Think about It? Journal of Dieticians Association of Australia, 61, 151-158, 2004.

[19] Insel, P.M. and Roth, W.T, Core concepts in health. Perspectives in Nutrition, ( ${ }^{\text {th }}$ edition), MacGraw Hill Company, Mosby Year Book, New York, 2004, 32-50. 
[20] Davies, J, Hammond's Cooking Explained (4 ${ }^{\text {th }}$ edition). Addison Wesley Longman Limited, Singapore, 2002, 25-26.

[21] WHO and FAO, Vitamin and Mineral Requirements in Human Nutrition ( $2^{\text {nd }}$ edition), Bangkok, Thailand, 2004.

[22] Gibson, R, Principles of Nutritional Assessment ( $2^{\text {nd }}$ edition), Oxford Press, New York, 2005, 5-9, 253-258.

[23] Lau, E. M., Lynn, H., Chan, Y. H., Lau, W. and Woo, J, Benefits of Milk Powder Supplementation in Bone Accretion in Chinese Children. Osteoporosis International, 15(8), $654-658,2004$.

[24] Damastuti, E., Ariyani, W.D., Santoso, M., Kurniawati, S. and Syahfiti, W.Y.N, Micronutrient daily intake of elementary schoolchildren in Bandung as determined by using NAA and AAS methods. Atom Indonesia, 37(2), 6270, 2011.

[25] Osei-Boadi, K., Lartey, A., Marquis, G.S. and Colecraft, E. $\mathrm{K}$, Dietary intakes and iron status of vegetarian and nonvegetarian children in selected communities in Accra and Cape Coast, Ghana. African Journal of Food, Agriculture, Nutrition and Development, 2012, ISSN 1684 5374, 12,1. Available:

http://www.ajol.info/index.php/ajfand/article/viewFile/7560 7/66144. Accessed August 4, 2013.

[26] Begum, R.M, Vitamins and Minerals. A Textbook of Foods, Nutrition and Dietetics, $3^{\text {rd }}$ Edition, Sterling Publishers Private Limited, New York, 2010, 49-74.

[27] Rea. C. Factors that influence eating behavior, 2007, Available:

http://www.revolutionhealth.com/articles?id=ug2146.

[28] Amos, P.M., Intiful, F.D. and Boateng, L, Factors that were found to influence Ghanaian adolescents' eating habits. SAGE Open October-December 2012 vol.2 no.4 $2158244012468140 . \quad$ Available: http://sgo.sagepub.com/content/2/4/2158244012468140.full. Accessed June 13, 2013.
[29] Puckree, T., Naidoo, P., Pillay, P. and Naidoo, T, Underweight and overweight in primary school children in eThekwini district in KwaZulu-Natal, South Africa. African Journal of Primary Health Care and Family Medicine, 3(1), Art. \#203, 2011, 6 pages. doi:10.4102/phcfm.v3i1.203.

[30] Prista, A., Maia, J.A.R., Damasceno, A and Beunen, G,Anthropometric indicators of nutritional status: implications for fitness, activity, and health in school-age children and adolescents from Maputo, Mozambique, American Journal of Clinical Nutrition, 77 (4), 952-959, April 2003.

[31] Malekzadeh, J.M, Hatamipour, E and Afshoon, E, ProteinEnergy Malnutrition in school children of Boirahmad Rural Areas, Iran, Iranian Journal of Public Health, 32 (3), 41-46, 2003.

[32] ACC/SCN, Overweight and Obesity: A New Nutrition Emergency, Geneva, 2005, ACC/SCN 2005:21.

[33] Adamu, A., Adjei, G.N.K. and Kubuga, K.C. (2012). Effects of dietary patterns on the nutritional status of upper primary school children in Tamale Metropolis, Pakistan Journal of Nutrition, 11(7), 591-609, 2012.

[34] Owusu, A, O'Hara Murdock, P, and Weatherby, N.L, Measuring nutritional intake of adolescents in Ghana, West Africa, International Electronic Journal of Health Education, 10, 104-113, 2007.

[35] Intiful, F.D., Ogyiri, L., Asante, M., Amoako Mensah, A., Steele-Dadzie, R.K. and Boateng, L, Nutritional status of boarding and non-boarding children in selected schools in the Accra metropolis. Journal of Biology, Agriculture and Healthcare, ISSN 2225-093X, 3 (7), 2013.

[36] MO-NUPA-01, Adolescents Nutrition, Available: http://www.cdph.ca.gov/HealthInfo/healthyliving/childfamil y/Documents/MO-NUPA-01 Adolescent Nutrition.pdf. 